Keywords: $M C U, A R P, I S D P$

Retention: Permanent

\title{
Results of Analyses of the Macrobatch 4 Tank 49H Confirmatory Sample
}

\section{T. B. Peters \\ S. D. Fink}

February 2012

Savannah River National Laboratory Savannah River Nuclear Solutions

Aiken, SC 29808

Prepared for the U.S. Department of Energy under 
SRNL-STI-2012-00024

Revision 0

\section{DISCLAIMER}

This work was prepared under an agreement with and funded by the U.S. Government. Neither the U.S. Government or its employees, nor any of its contractors, subcontractors or their employees, makes any express or implied:

1. warranty or assumes any legal liability for the accuracy, completeness, or for the use or results of such use of any information, product, or process disclosed; or

2. representation that such use or results of such use would not infringe privately owned rights; or

3. endorsement or recommendation of any specifically identified commercial product, process, or service.

Any views and opinions of authors expressed in this work do not necessarily state or reflect those of the United States Government, or its contractors, or subcontractors.

\section{Printed in the United States of America}

Prepared for

U.S. Department of Energy 


\section{REVIEWS AND APPROVALS}

\section{AUTHORS:}

T. B. Peters, Author, SRNL/SASP

Date

TECHNICAL REVIEW:

C. A. Nash, Technical Reviewer, SRNL/ACP

Date

APPROVAL:

S. D. Fink, SRNL/SASP, Manager

Date

S. L. Marra, SRNL/E\&CPT Research Programs, Manager

Date

D. J. Martin, Manager, H Tank Farm Engineering

Date 


\section{EXECUTIVE SUMMARY}

Savannah River National Laboratory (SRNL) analyzed samples from Tank 49H in support of qualification of Salt (Macro)Batch 4 for the Integrated Salt Disposition Project (ISDP). This document reports the results of the analyses of the confirmatory sample of Tank 49H. All sample results either agree with expectations based on prior analyses or are considered trivial enough not to warrant concern. No issues with the projected Salt Batch 4 strategy are identified. 


\title{
LIST OF ABBREVIATIONS
}

\author{
AD - Analytical Development \\ ARP - Actinide Removal Project \\ ICPES - inductively coupled plasma emission spectroscopy \\ ISDP - Integrated Salt Disposition Project \\ RSD - Relative Standard Deviation \\ SRNL - Savannah River National Laboratory \\ TIC-TOC- total inorganic carbon-total organic carbon \\ TTQAP - Task Technical and Quality Assurance Plan \\ TTR - Technical Task Request \\ $\%$ RSD - percent relative standard deviation
}




\subsection{Introduction}

This report describes the laboratory results of Salt (Macro)Batch 4 confirmatory sample. These results will be used by Tank Farm Engineering for their blend calculations. This work was specified by Technical Task Request (TTR) ${ }^{1}$ and by Task Technical and Quality Assurance Plan (TTQAP). ${ }^{2}$

Details for the work are contained in controlled laboratory notebooks. ${ }^{3}$

\subsection{Experimental Procedure}

A Tank49H sample (i.e., dip sample bottle HTF-49-11-108) arrived at SRNL on October 10, 2011. The sample was optically clear, with no visible solids present. The researchers measured the density of the solution (Table 1).

After the density measurements, samples were sent to Analytical Development (AD) for analysis.

\subsection{Results and Discussion}

Table 1. Density Result from the Tank $49 \mathrm{H}$ Sample $\left(25^{\circ} \mathrm{C}\right)$

\begin{tabular}{|c|c|}
\hline Sample & Density Result $\mathbf{( g / m L )}$ \\
\hline HTF-49-11-108 & 1.271 \\
\hline
\end{tabular}

The analytical uncertainty is typically $<1 \%$ for density measurements. After the density measurement, samples were sent to $\mathrm{AD}$ for analysis.

The tank samples were analyzed by Analytical Development (AD) for cesium content by Inductively Coupled Plasma Emission Spectroscopy (ICPES), for free hydroxide, anion content, for Total Inorganic Carbon-Total Organic Carbon (TIC/TOC).

Table 2 shows the results from the analyses for the Tank $49 \mathrm{H}$ sample. 
Table 2. Chemical Results for the Tank $49 H$ Analyses

\begin{tabular}{|c|c|c|}
\hline Analyte & Result (\%uncertainty) & Expected Value \\
\hline $\mathrm{Al}$ & $4110 \mathrm{mg} / \mathrm{L}(10 \%)$ & $4104 \mathrm{mg} / \mathrm{L}$ \\
\hline $\mathrm{K}$ & $381 \mathrm{mg} / \mathrm{L}(10 \%)$ & $452 \mathrm{mg} / \mathrm{L}$ \\
\hline $\mathrm{Na}$ & $151000 \mathrm{mg} / \mathrm{L}(10 \%)$ & $157000 \mathrm{mg} / \mathrm{L}$ \\
\hline $\mathrm{Si}$ & $61.3 \mathrm{mg} / \mathrm{L}(10 \%)$ & $73.9 \mathrm{mg} / \mathrm{L}$ \\
\hline Free Hydroxide & $2.81 \mathrm{M}(10 \%)$ & $2.65 \mathrm{M}$ \\
\hline Total Base & $3.12 \mathrm{M}(10 \%)$ & $\mathrm{N} . \mathrm{A}$. \\
\hline Total Inorganic Carbon & $3120 \mathrm{mg} / \mathrm{L}(10 \%)$ & $2900 \mathrm{mg} / \mathrm{L} *$ \\
\hline Total Organic Carbon & $260 \mathrm{mg} / \mathrm{L}(10 \%)$ & $\mathrm{N} . \mathrm{A}$. \\
\hline nitrate & $156000 \mathrm{mg} / \mathrm{L}(10 \%)$ & $197000 \mathrm{mg} / \mathrm{L}$ \\
\hline nitrite & $39000 \mathrm{mg} / \mathrm{L}(10 \%)$ & $41300 \mathrm{mg} / \mathrm{L}$ \\
\hline sulfate & $4890 \mathrm{mg} / \mathrm{L}(10 \%)$ & $6390 \mathrm{mg} / \mathrm{L}$ \\
\hline chloride & $118 \mathrm{mg} / \mathrm{L}(10 \%)$ & $148 \mathrm{mg} / \mathrm{L}$ \\
\hline phosphate & $508 \mathrm{mg} / \mathrm{L}(10 \%)$ & $447 \mathrm{mg} / \mathrm{L}$ \\
\hline oxalate & $121 \mathrm{mg} / \mathrm{L}(10 \%)$ & $192 \mathrm{mg} / \mathrm{L}$ \\
\hline 137 Cs & $5.54 \mathrm{E}+07 \mathrm{pCi} / \mathrm{mL}(5.00 \%)$ & $5.45 \mathrm{E}+07 \mathrm{pCi} / \mathrm{mL}$ \\
\hline
\end{tabular}

N.A. = analyte concentration was not predicted

* as carbonate

\subsection{Conclusions}

All sample results either agree with expectations based on prior analyses or are considered trivial enough not to warrant concern. No issues with the projected Salt Batch 4 strategy are identified. 


\subsection{References}

${ }^{1}$ A. R. Shafer, “Qualification of ISDP Salt Batch 4”, HLW-DWPF-TTR-2010-0035, September 14, 2010.

${ }^{2}$ T. B. Peters and S. D. Fink, "Task Technical and Quality Assurance Plan for ISDP Salt Batch 4 Sample Qualification”, SRNL-RP-2010-01433, Rev.0, November 30, 2010.

${ }^{3}$ T. B. Peters, “ISDP4”, SRNL-NB-2011-00027, February 18, 2011. 


\section{Distribution:}

E. J. Freed, 704-56H

D. J. Martin, 241-152H

M. W. Geeting, 241-152H

B. A. Gifford, 704-56H

S. P. McLeskey, 241-152H

K. L. Lang, 704-27S

B. A. Oard, 241-197H

R. E. Edwards, Jr., 773-67A

K. D. Harp, 766-H

S. L. Marra, 773-A

A. B. Barnes, 773-A

C. C. Herman, 99-W

B. J. Giddings, 786-5A

F. M. Pennebaker, 773-42A

S. D. Fink, 773-A

T.B. Peters, 773-42A

C. A. Nash, 773-42A

F. F. Fondeur, 773-A

P. R. Jackson, 703-46A 